\title{
Understanding Government Purchasing Public Services in China: Case Study of Guangdong and Yunnan*
}

\author{
Liheng Qi, Jia Guo \\ School of Government, Beijing Normal University, Beijing, China \\ Email: 201321230026@mail.bnu.edu.cn
}

How to cite this paper: Qi, L.H. and Guo, J. (2017) Understanding Government Purchasing Public Services in China: Case Study of Guangdong and Yunnan. American Journal of Industrial and Business Management, 7, 312-327.

https://doi.org/10.4236/ajibm.2017.73022

Received: February 13, 2017

Accepted: March 28, 2017

Published: March 31, 2017

Copyright $\odot 2017$ by authors and Scientific Research Publishing Inc. This work is licensed under the Creative Commons Attribution International License (CC BY 4.0).

http://creativecommons.org/licenses/by/4.0/

\begin{abstract}
The collaboration between public sector and social organizations has already become a major trend in terms of public service delivering in China. This article aims to provide a systematic framework for better understanding the regional variations of local government purchasing public services from social organizations. Drawing upon comparative case study between Yunnan and Guangdong provinces, it highlights how critical factors, such as the level of local economic development, the environment, policy supports and the quality of social organizations, affect government purchasing public services in these two regions. The forms and contents of government purchasing public services may vary across regions in which financial support and social organization's professional cannot compete equally. Hence, the article suggests that local government has to define the range and content of public service based on the local variations as well as needs of local citizen.
\end{abstract}

\section{Keywords}

Regional Variations, Local Governments, Purchasing Public Services, Social Organization

\section{Introduction}

Government purchasing public service is the core of government procurement, and also the value of government procurement. Defining the forms and content of government purchasing public services means that managers need to determine what kinds of public services the government can purchase, what kinds of public services are prohibited. It should be noticed that the starting point of China and western government purchasing public services is different; it starts *The original draft has been presented at 16th Annual Research Postgraduate Conference, and we have revised the manuscript. 
from the premise that since the 1970s, the western welfare state has been increased the social welfare spending drastically, causing government fiscal deficits. But at the same time, the government has been unable to meet the actual public demands for public services. By the early 1980s, there was a much greater understanding than ever before that market competition mechanism had a huge potential role in saving government financial expenditure and public services supplementing. In order to get rid of the public service shortage dilemma, the government purchasing public service is gradually emerging.

Compared with Western countries, the emergence of Chinese Government purchasing public service is to adapt to government functions reform. The development law of Chinese government purchasing can be embodied from points to surfaces, from top to bottom. In 1995, Shanghai became the first to explore the government purchasing public services' model. Since 2003, the developed areas, such as Shenzhen, Guangzhou and Beijing, have set to implement the purchasing model. And then the purchasing model becomes popular in the whole country. The state council leading group office of poverty alleviation and development, Asian development bank, Jiangxi poverty alleviation and resettlement office and China foundation for poverty alleviation launched "Non-governmental organizations to cooperate with the government in village level poverty alleviation pilot project", marked the Chinese government purchasing public service into standardized pilot.

With more and more local governments beginning to purchase the public service, the purchasing model steps into the stage of systematic construction. Since the early 2000s, China's national authorities have been issued new social organization regulations. The government procurement law of People's Republic of China, in Jun 2002; the implementation rules for the central finance supporting social organizations to participate in social service projects in 2012; the guidance for government purchasing public services with social organization in September 2013; the regulation for the government procurement for the People's Republic of China in December 2014 and the management measures for government purchase services in December 2014, these legislative measures constantly promote the systematic construction of government purchase, clarify the rights and obligations between the government and social organizations, and the government legitimacy to purchase public services.

From the perspective of the public administration, at the present stage Chinese overall public service provision is out of balance, between the eastern and western regions, urban and rural, the public service supplementing is imbalance and alarming. Contradictions in citizen demands for public services and insufficient supply of public services have become increasingly prominent, the number and quality of public services has not met the real needs of citizens. With this understanding, came to realization that Chinese government has started the third stage of public administration reform-building a service-oriented government, and plan to achieve the goal of public services equalization by 2020 . With the deepening of administrative reform, the contents and scope of government 
purchasing public service is changing, not simply some products of "government decided", the need became clear for a more core effect of regional variation in local government purchasing public services, and greater attention to understanding the real needs of local citizen to drawing the contents of government purchasing guidance.

The key research questions addressed in the paper are, firstly, what kinds of public services have been purchased by local government since the central government issued Government purchase service management approach (interim) in 2014, and, secondly, how does regional difference affect the forms and contents of local government purchasing.

The paper aims to develop a comparison of Yunnan and Guangdong regarding local government purchasing public service contents. The paper highlights case studies of two local government procurement practice which exemplify the different contents in local government purchasing. The data gathering demonstrate that local authorities have responded to the real needs of local citizens, and purchased some special public services from local social organizations. In particular, the paper illustrates why we need change the content of public services purchased by local government, and how the regional difference effect the local government procurement practice. Information on local economic resources is accessed through "The China Statistical Yearbook (2012-2015)", information on social organization is accessed through Ministry of Civil Affairs the People's Republic of China, and the department of civil affairs of Guangdong Province and Yunnan Province.

\section{Literature Review}

\subsection{Literature Bibliometrics of Chinese Scholars' Work}

Citespace is the latest development of a generic approach to detecting and visualizing emerging trends and transient patterns in scientific literature. The method facilitates analytic and sense making tasks by integrating network visualization, spectral clustering, automatic cluster labeling, and text summarization (2010) [1]. Since 2000, government purchasing public service has become a hot topic in the field of public administration in China (please see Figure 1). More than 1200 articles about government purchasing public service were included in the CNKI database during 2000-2017 (Core Journal and CSSCI). It is a great challenge for digesting the vast volume of data, we will use Citespace to analyze the collected data. Citespace is a software for characterizing and interpreting the structure and dynamics of co-citation. The method facilitates analytic and sense making tasks by integrating network visualization, spectral clustering, automatic cluster labeling, and text summarization (2010) [1].

Hot research topics and frontline research in the government purchasing field were identified on frequency of popular key words used in journal articles. The collection of literature data is the key to run Citespace software, first of all, we take "government purchasing public service" as the terms to retrieve all articles 


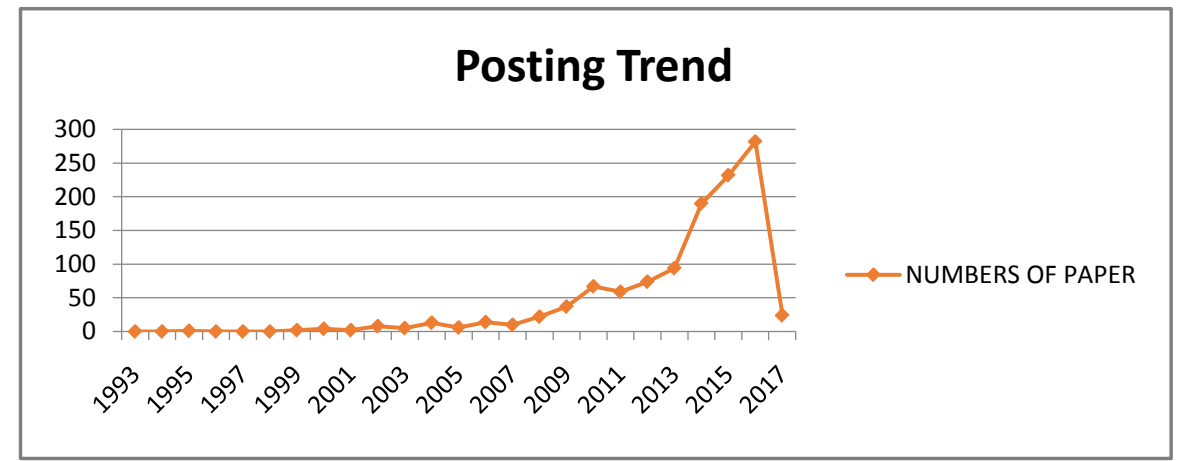

Figure 1. Publications of government purchasing public services during 1993-2017.

collected in CNKI database in (published from 2001-2017), and book reviews and editorial letters should be excluded to eliminate "noise" in the database. A total of 1160 articles were retained.

Before we run Citespace, we should be set following parameters in Citespace: 1) Time Slicing from 1993 to 2017, year per slice: 2 years; time slicing refers to the published time of bibliographic records in the CNKI database; 2) Term source $=$ title/abstract/author keywords/keywords plus; the topical terms are used to retrieve bibliographic records from CNKI; 3) Node type = key word; 4) Pruning $=$ pathfinder/pruning the merged network; pathfinder network is superior than a multidimensional scaling in terms of preserving the chronological growth patterns in co-citation networks; 5) Select 20 most cited articles per slice. The highest cited literature indicates the representativeness of the cited literature in this field.

After running Citespace, we got the map shown in Figure 2. The clustering function was performed by choosing " $K$ " as the labelling source and log-likelihood ratio as the method. Citespace provide Modularity Q and Mean Silhouette to evaluating the effect of the map. When $Q>0.3$, the structure of map is significant; when Mean Silhouette is 0.7 , the clustering is efficient and convincing. Generally speaking, the values of Mean Silhouette should be between -1 to 1 . Values close to 1 mean articles within a cluster are highly consistent or similar in terms of content. Figure 2 shows that the Modularity Q value is 0.7473 which means that the structure of the map of government purchasing is significant; and the Mean Silhouette is 0.538 . It means that the map has higher reliability.

\subsection{Knowledge Structure Map}

Specifically, from Table 1, we can see that the cluster ranked first was transformation of government function (\#0). This knowledge cluster contains public services purchasing $(18.78,1.0 \mathrm{E}-4)$. This cluster contained 17 articles, mostly published around 2012. The silhouette value of the cluster was 0.879 , indicating high consistency among the 36 cited articles in this cluster, with Su Ming, Jia Xijin, Han Junkui (2010) article on Chinese government purchasing public services research being referenced most often. The second largest cluster (\#1) contains 16 articles with a silhouette value of 0.896 and a total of 30 citations. Fang Guobing's 


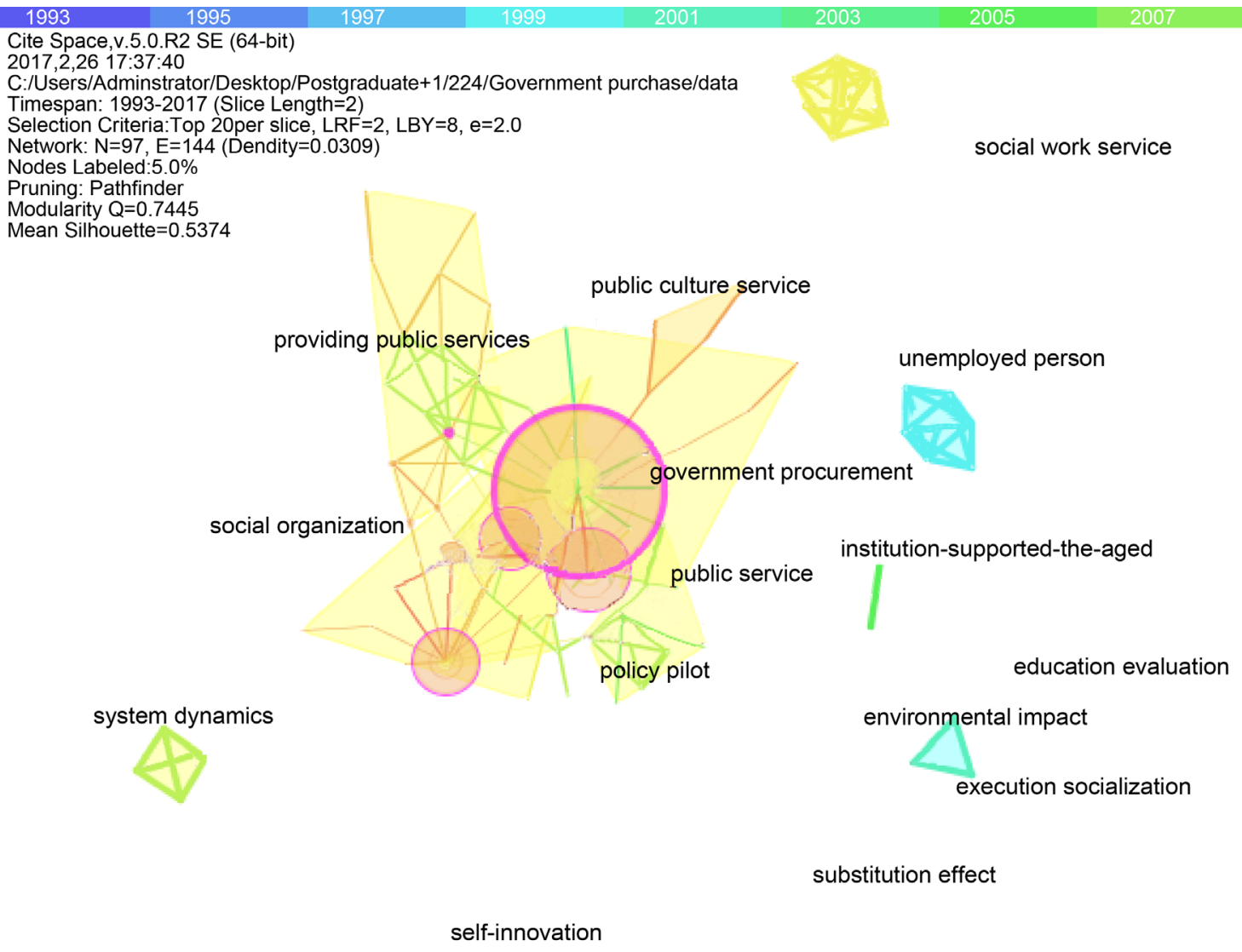

Figure 2. Co-citation clusters of cited.

Table 1. The result of document co-citation.

\begin{tabular}{|c|c|c|c|c|}
\hline Cluster ID & Size & ilhouette & Mean (year) & Top Terms (log-likelihood ratio, p-level) \\
\hline 0 & 17 & 0.879 & 2012 & $\begin{array}{l}\text { Transformation of Government Function }(18.78,1.0 \mathrm{E}-4) \\
\text { public services purchasing }(18.78,1.0 \mathrm{E}-4)\end{array}$ \\
\hline 1 & 16 & 0.896 & 2011 & $\begin{array}{l}\text { Public service delivery }(49.67,1.0 \mathrm{E}-4) \text {; quality of public } \\
\text { service }(40.83,1.0 \mathrm{E}-4)\end{array}$ \\
\hline 2 & 16 & 0.753 & 2008 & $\begin{array}{l}\text { Government purchase }(53.68,1.0 \mathrm{E}-4) \text {; public service } \\
\quad(18.3,1.0 \mathrm{E}-4) \text {; input mode }(14.04,0.001)\end{array}$ \\
\hline 3 & 8 & 0.923 & 2008 & $\begin{array}{l}\text { Policy pilot }(36.72,1.0 \mathrm{E}-4) \text {; rural area }(36.72,1.0 \mathrm{E}-4) \text {; } \\
\text { one body two wings }(36.72,1.0 \mathrm{E}-4)\end{array}$ \\
\hline 4 & 7 & 1 & 2011 & Local knowledge (100.21, 1.0E-4) \\
\hline
\end{tabular}

(2010) article on re-constructing the new relationship between government and NGO's-the exploration and practice in Shanghai was the most cited. Jesse D. Lecy, Davis M. Van Slyke (2016) article on nonprofit sector growth and density: testing theories of government support describe the relationship between government and nonprofit sector emphasizes the effecting of government funding on nonprofit density.

Depend on the result of document co-citation analysis, the Chinese academic point of view is mainly reflected in three aspects: 1) The first viewpoint focuses on the different cooperation relationship between social organizations and government; 2) The second view focused on the different original motivation of 
government procurement of public services; 3) The third view focused on a specific public services purchased by local government is the starting point, making a concrete analysis on different regions government purchasing public services arising various problems.

Preferences that result from diversity in a society are referred to as heterogeneous demand, which are assumedly met through the incorporation of specialized nonprofits. The relationship between the government and the social organization has become a research focus. WANG Ming and LE Yuan (2008) found that social organizations to participate in government purchasing public services in three modes, which are independent on noncompetitive purchase, independent on competition purchase and independent on noncompetitive purchase. By comparing these three modes showed that social organization and government have comparative advantages on the provision of public services, they also proposed new ideas that social organizations have to maintain independence and improve the mechanism of competition between the government and social organizations [2]. According to developed countries self-push pattern and developing countries external-drive pattern as the division standard, the social organizations participate in the government purchasing divided into competitive and non-competitive purchase, while the non-competitive purchasing was divided into two modes again: System internal absorption patterns and informal on the need to buy patterns (HAN Jun-Kui, 2009) [3].

The government failure theory and market failure theory are described the development motivation of social organization. Different from the western countries, the Chinese government purchasing public service has different motives. YANG An-hua (2014) summarized the three main motivations that Chinese government purchasing public services from the social organizations that are the important supporting force for implementing public service privatization reform is the market methods like government purchasing services can save cost, improve service quality, and reduce the size of government. However, YANG An-Hua think the government purchasing public services are not fully achieve the original idealistic goals, and instead, at present Western governments appeared the embarrassment repurchasing public service situation, and as a warning to put forward important recommendations on the Chinese government purchasing public service [4]. ZHENG Heng-Feng (2014) summarized the dynamic mechanism that the local government purchasing public services from social organization in three points: to meet the diverse needs; to make up for insufficient financial resources and create public image [5].

The third view focused on the process of local government purchasing public service. XU Jia-Liang, Zhao Ting (2013) took Shanghai government purchasing public services to the social organization as the research objective, while affirming the Shanghai government procurement of public services has made some progress, he found that they have some issues on legal guarantees, budget management, purchase process information communication and put forward relevant suggestions [6]. Xiang Xiansheng (2015) point out the livelihood issues, publicity, 
authority restriction and operability are the main influence factors of government purchasing public service. The idea that misplaced guiding thought, unclear definition scope, weak feasibility, low legislation and inconsiderate regional differences can affect the boundary government purchasing public services [7]. This is especially surprising a boundary issue, this article have made the connection between government purchasing and Regional Variations more evident.

Most of Chinese scholars focus on the above aspects to analyze the differences of issues for government purchasing public services, but in real sense, to study on the government purchasing difference public service contents is inadequate. Firstly, we need to define the meaning of the difference contents of public service. Local government purchasing difference public service content refers to in different regions government purchasing public services, the type of public service appears discrepancy, different regions' local government have different focus point on procurement of public services. Through the study on purchase of public service difference content, we can analyze the level of public service provision in different areas and understand the real needs of the local public of public services, meeting the different needs of different areas of public service. This article tries to Identifying regional variations (e.g., microeconomic, policy) and determining how they affect local government purchasing difference of public service contents to guide the local government to provide public service efficiently, and improving the sense of satisfaction of citizen to public service.

\section{Exploring the Effects of Regional Variations}

\subsection{The Status Quo of Chinese Government Purchasing Public Service}

In this section, a content framework is developed which allows a more detailed characterization of local government procurement practice. Therefore we selected the data of Guangdong province and Yunnan province purchasing public service from 2012-2016, ${ }^{1}$ this framework incorporates two kinds of contents in public procurement: the move to more equal public services; and the move to more complex and diversification public services. The combination of these two trends produces a more dynamic and operability local government purchasing public service guidelines.

June 27, 2014 in Guangdong government released the first Guangdong Social Work Development Report (2014), the report showed that the numbers of social organization, the total funds of Guangdong government purchasing public services and the number of social workers who access national occupational certification, these three indicators rank first in China [8]. At the end of 2015, Guangdong province has 54,775 registered social organizations, including 25,379 social organization, 28,418 people-run non-enterprise units and 678 foundations [9]. And from the history of Chinese government purchasing public service,

${ }^{1}$ This study draws on two secondary data sources. Information on local economic resources is accessed through the China Statistical Yearbook, 2012-2014. Information on social organization is accessed through local government report and news. 
Guangdong Province is the initial pilot areas to achieve the government purchasing public services, now Guangdong province has formed a characteristic model of government procurement, in 2008 the Guangdong provincial government would through authorized delegate and otherwise ways transfer three categories of 17 government functions to community organizations [10]. At November 30, 2015 Guangdong government drafted "Regulations of Guangdong Province on social organizations (Draft)", this is the first local regulation that drafted by local government, it will make contributions to developing social organization of China [11].

Yunnan province is known as the "cradle of China NGO", it is the fastest growing province of western region in government purchasing public services to social organization field. In 2013 and 2014, Yunnan Province have a total of 40 social organizations obtain "Central financial support for social organizations to participate in social service projects", and a total of 12.17 million funding support, the total amount of funds ranked third in China. And by June 30, 2013, per million citizen of Yunnan province has 3.39 social organizations, this number is close to the national average, it ranks second only to Sichuan Province in western region [12]. However, the Yunnan government purchasing public services to the social organization began in November 2009; Provincial administrative institutions employ accounting, cost consulting, asset valuation and other intermediary services included in the scope of government purchasing public services for the first time. And through public bidding Yunnan local government introduced accounting firms, cost consultancy and asset evaluation agencies and other intermediary service organizations total 99 social organizations as government appointed purchasing undertaker to provide public services [13]. In 2014, Yunnan local government issued 2014 provincial government purchase social organization service catalog that clearly defines the scope of public services that Yunnan local government buy to the social organization [14]. Yunnan local government has amended "the directory of Yunnan government purchasing public services to social organization" till April 10, 2016. They provide clear illustrations of contents in which local government procurement [15].

The real needs of local citizen can help to realize the values of public service procurement. The content of Guangdong and Yunnan government purchasing public services is actually different now, so we chose the Guangdong Province and Yunnan Province as China's eastern and western regional government representative to study local government purchasing difference public services contents, and the impact factors of these differences.

From Table 2, we can see in 2009 Guangdong Provincial Government in community service, community services for the aged, urban public transport services, consulting services, vocational training, industry appraisals, decisionmaking demonstration, outcomes assessment and other aspects developed priority government purchase pilot work. In 2012 Guangdong provincial government to accelerate the improvement of public education, public health, public culturaland sports, housing, employment, pension, health care and rehabilitation security 
Table 2. The scope of government purchase public service in Guangdong Province and Yunnan Province [14] [16].

\begin{tabular}{|c|c|c|}
\hline Content & Guangdong Province & Yunnan Province \\
\hline \multicolumn{3}{|c|}{2008} \\
\hline The original & Industry management and coordination function, social & 2009 \\
\hline $\begin{array}{l}\text { government purchase } \\
\text { public service content }\end{array}$ & $\begin{array}{c}\text { affairs management and service function, technical } \\
\text { service function and market supervision and } 3 \\
\text { categories, } 17 \text { functions }\end{array}$ & $\begin{array}{l}\text { Provincial administrative units hiring accounting, } \\
\text { cost consulting, asset valuation and public services }\end{array}$ \\
\hline
\end{tabular}

and other basic public service system, and local government relaxed the entry threshold of social organization in these areas [17].

Guangdong government purchasing public services contents has started from the traditional areas of care services, disability services, youth services, community services, employment services and gradually expand to judicial correction, health care, educational consultation, marriage and family, the new rural construction, service for migrant workers, volunteer services and other new fields. From civil administration departments, disabled persons' federation expanded to justice, education, health, trade unions, Youth League other departments and organizations, and gradually formed a new pattern of multi-sector, multi-organizational, multi-field purchase public services [16].

However, due to the overall level of underdevelopment, just like Table 2 show, Yunnan government purchasing public services still remain in the traditional areas related to public basic health care, education, poverty alleviation, disaster, environmental, cultural, and AIDS prevention and control. According to the new direction, departments at different levels in Yunnan province can accord economic and social development of the regions to adjust the content of purchased public service. The new directory highlight the publicity and commonweal of government purchasing, such as education, employment, social insurance, social assistance, disability services which are directly related to the livelihood of the two category accounted for about 50\% [18]. Especially in 2015 Yunnan government will provide 9.08 million for AIDS intervention and support.

\subsection{Researching of the Cause of the Difference of Local Government Purchasing Contents}

In the last decade, there have been a number of important drivers of change in China which reflect new practices in local government purchasing public services. The first key driver of these different procurement contents is the level of local economic development. And the second one is strong financial support. To create the local government purchasing construct, principal component analyses were performed on the following four economic indexes: local GDP, revenues, CPI and financial funds. Full results of the principal component analyses for 
each year are provided in Table 3 (local government) and Table 4 (central government).

In the early, the level of local economic development is the priority reason to Chinese government chose the eastern coast cities to develop government procurement of public services pilot work. The level of economic development promote the demand for diversification of public services, the demand for basic public services of education, health care and other service are gradually growth, personalized service demand are also increasing. The developed regions have enough fiscal to support the behavior of government purchase, and the capability of local household consumption can satisfy purchasing desire of public service.

A recent survey suggested that when a country's per capital GDP more than 3000 US dollars, the public service of the whole society is quite different [19]. Table 3 shows the size of Guangdong local GDP, there is an increase of 500 billion in 2013, and it is five times than the GDP of Yunnan province. As well as in 2013 the household consumption of Guangdong province is two times of Yunnan provinces', the local fiscal revenue is nine times of Yunnan provinces'.

In 2014 Yunnan provincial financial arrangements 28.44 million for the purchasing services to social organizations, at the same time Guangdong province invested about 57 million to buy social workers service, the local financial investment in the proportion of $86.1 \%$. In 2015 Guangdong local government invested more than 1.1 billion Yuan to purchasing public services to social organizations. The local fiscal support of Yunnan government reached 121.8355 million Yuan, but there is still a huge gap between two local government fiscal supports.

The local government is the main fiscal supporter to buy public service from social organization, the local financial revenue determines the capability of local government procurement directly. Visibly, high speed economic development of developed areas have promotion effect to local government purchase public services, it accelerates the government purchase public services, and increase the number of community public service provision. In sum, the results from the

Table 3. The level of Yunnan and Guangdong provinces' economic development.

\begin{tabular}{|c|c|c|c|c|c|c|}
\hline \multirow[b]{2}{*}{ Province } & \multicolumn{6}{|c|}{ The level of local economic development } \\
\hline & Year & $\begin{array}{c}\text { Local GDP } \\
(1000 \text { million })\end{array}$ & $\begin{array}{l}\text { Household } \\
\text { consumption }\end{array}$ & $\begin{array}{c}\text { Public budgetar } \\
\text { revenue } \\
\text { (1000 million })\end{array}$ & $\begin{array}{l}\text { Public budgetary } \\
\text { expenditure } \\
\text { (1000 million) }\end{array}$ & CPI (last year $=100)$ \\
\hline Yunnan & 2013 & 1183.231 & 11,224 & 161.13 & 409.651 & 103.1 \\
\hline Guangdong & & 6247.479 & 23,739 & 708.147 & 841.1 & 102.5 \\
\hline
\end{tabular}

Table 4. Central government delegated public service items.

\begin{tabular}{ccccccc}
\hline \multirow{2}{*}{ Region } & \multicolumn{3}{c}{ Number } & \multicolumn{3}{c}{ Funds (million) } \\
\cline { 2 - 7 } & 2012 & 2013 & 2014 & 2012 & 2013 & 2014 \\
\hline Yunnan & 20 & 20 & 21 & 6.4 & 5.77 & 6.34 \\
Guangdong & 6 & 6 & 7 & 2.15 & 2.1 & 3.28 \\
\hline
\end{tabular}


analyses suggest theory and empirical data come together. It empirically supports that economic development is important to social organization, and it also shows that government's attitude decided the development of social organization.

From the history of China, Guangdong province is the earliest open coastal port. Since Reform and Open in 1978, Chinese government determined Guangdong and the other eastern coastal province as economic development zone, and government issued a series of policies to promote economic and social development of Guangdong. In 1990s Chinese government carried out government purchasing public service in Guangdong and Shanghai firstly, and created the new field of government buy to social organization service.

And now, for solving the problem of public service equalization, government start shift its policy to western underdevelopment area. From Table 4 we found that in the past three years Yunnan local social organizations undertook 61 public services which central government delegated, accepted 1851 million allocate funds during 2012-2014, and Guangdong social organizations won 19 national projects and a total of 7.53 million funds [20]. Compared the data of two provinces, we found that central government provided more financial funds to meet the huge demands of local citizen in western region for public services. In 2015 central government will support social organizations to participate in 446 national projects and provide 195 million Yuan financial funds. However, the financial support is not enough to help the full development of Yunnan social organizations.

In 2014 Ministry of Finance issued Government purchase service management approach (interim) sets the main content of government purchasing public services, the management approach didn't provided compulsively to local government procurement of specific public service contents, central government should devolution to local government more privileges to design the suitable purchase directory, to avoid the irrational behavior of government procurement of public services.

A third key driver of these different procurement contents is the differences of natural environment. Compared to the eastern region, the western region has a completely different culture and natural environment. Geographical differences results in the local government purchasing difference public service contents to some extent. Yunnan province located in the southwest border of China, adjacent to Vietnam, Laos, Myanmar, but its geographical location also led to many problems like drug abuse and HIV infection and so on. The topography of Yunnan province is mountainous, natural disasters hits frequently, so in Yunnan local government focus more on to buy AIDS prevention and disaster relief public service, together with Yunnan geographically isolated, it lacks of economic development pillar that led to the lack of public health and education resources. Thus, the inefficient supply of public service led to much dissatisfaction.

Guangdong Province is located in China's southeast coast, it is an important port of our country turned global in history, and it has the advantage that adjacent to Hong Kong, P.R. China and Macao P.R. China. Hong Kong P.R. China 
has become its learning objects to help Guangdong government to create local specialties buying patterns. Guangdong Province introduced social institutions and developed social workers service in Guangdong Province. In the pilot stage of the government purchase public services, the local government focus on the field of public health service, public education, poverty alleviation, and now it formed fully competition mechanism in these traditional purchase fields, market survival mechanism covering all social organization, so these organizations can provide higher quality and efficient public service to citizen.

Governments benefits from stable relationships with nonprofits because risk is managed, goods are produced, services delivered, and the costs of rebidding contracts or awarding grants to new and potentially unknown recipients are lowered (2016) [21]. Therefore the social organization as the accepting side is the important parts in the process of government purchasing public services. The development quality of social organizations determines whether the local government willing to bring them into the main provision bodies of public services, and determines the social organizations to undertake the public services supplier whether can improve the efficiency and quality of public services.

During 2012-2014 the number of social organizations in Guangdong and Yunnan province is growing, by 2014, Yunnan Province registered a total of 19,959 social organizations, and the number of social organizations in Guangdong Province reached 46,835 in 2014, it is almost two times of Yunnan provinces'. The developed social organization in Guangdong province provides more choice for government to purchasing public service, and there are more professional social organizations than Yunnan province.

The embarrassment situation in western region is that there lacks social organizations which can match conditions of local government. So we can see that it's a problem that the qualification of social organizations is not up to delegated public service standard of local government. Before we solved the quality problem of social organizations we blind undertake public service which delegated from government, it will lead to poor quality and inefficient public service provided, even it will bring serious rent-seeking problem in process of procurement.

\section{Discussion}

This article examines two of the most important trends in government purchasing public services. The move to more equal public services; and the move to more complex and diversification public services which best explain the existing boundary issue of government purchasing public services content. With the continuous development of social economy, differentiated demands for public services is increasingly clear, between the eastern and western provinces, local government purchasing public service contents appears significant differences. The local governments in western areas according to its own level of development as well as the requirements of local public to buy appropriate public services, and in recent years, the national policy adapted preferential policy in western regions to provide a strong policy and financial support to local gov- 
ernment purchasing public services, they also consolidate the scope of existing purchasing public service contents in the western region, and increasing the traditional public services supplies. The local government of eastern region is dependent on its strong financial revenue, providing support for local government procurement of public services, and constantly improve competition mechanism in the field of the traditional local government procurement of public services, and continue to expand the local government procurement of public service contents.

With the deepening study of local differentiated public service contents, the needs of the different local citizen seemed very different and it has hard to envisage designing a fixed guideline of government procurement. These two case studies provide the factors of which to effect local government procurement. Different region governments should be local demand-oriented to better meet the real needs of the public, and eliminate the negative impact that the local government cannot met the public needs for public service, and blind expansion of the regional social organizations. Therefore, based on the analysis of factors of local government procurement of difference public services contents, local governments need to constantly improve government procurement of difference public services contents, inter-regional need to change the situation of imbalance supply of public services.

The recognition that at this stage local government procurement cannot build a "quasi-fits-all" government procurement of public services directory, local governments should not be policy-oriented for buy public services. It means that procurement now has to solve the problem of the needs of citizens. Furthermore, local government procurement requires professional social organizations, the quality of social organizations effects on public service content. One reason for the rapid growth in the number of local social organizations is that they can quickly and timely perceive the service needs of local residents, and they can provide public services to meet the actual needs of the local residents as the starting point, where the social organization can provide public services better than government. Government needs to establish social organizations experts' think tank to solve internal management problems and external operational problems, social organization should improve the professionalism of themselves, and to provide opportunity to local government purchasing public services to choose the community organizations, we should make sure that form positive competition between social organizations. And local government support to social organizations is not limited to financial support, they also can provide more social security, infrastructure support, personnel training support to the social organization and these are security supports to the development of social organizations, they can relieve social organization's pressure from all sides, and government should help the weak social organization to grow health. Social Organizations possessing higher qualifications can not only understand the specific needs of the public service, they also can become powerful undertakers to provide these diversify public service. 
For the moment, the central government's financial support is an important funding source for the western underdeveloped regions' government procurement of public services. If local government put government purchasing public services into national finances system, they can clear specifically to purchase capital sources and to ensure the capital chain stability, it is conducive to the effective supply of public services. Second, the western region needs a clear structure of fiscal expenditure; they should have more investment to the shortage of basic public services field, and meet the needs of citizens for basic public services.

Fourthly, from the current contents of the local government purchased services, the contents scope of government purchased public service in western region is still relatively small, in the future there will be more public services should be included in the scope of the western regional government purchase, local governments need to adopt flexible ways to purchase in order to meet the demand for personalized services.

\section{Conclusions and Suggestions}

Clearly, four factors' data gathering cannot illustrate all the regional variations in local government purchasing public services highlighted above. However, these factors do illustrate some of regional differences of government procurement.

Firstly, they provide clear illustrations of contents in which local government procurement, the real need of local citizen can help to realize the values of public service procurement. Furthermore, avoiding Government purchase service management approach (interim) issued by central government is a mere formality; the real needs of local citizen cannot be satisfied.

Secondly, in each of provinces' studies, it does appear that the strongest driver for difference public services is the social need. This indicates that local government procurement process may indeed respond to the call for more citizen involvement in public service procurement.

Thirdly, it was only to be expected that new provider of public service would be needed to change the monopoly position of central government in public service providing. However, the social organization in western regions which are highlighted in this article, still needs to be more support to fulfill its potential of supply side in government procurement.

This article provides a framework which outlines the key differences between eastern and western local governments in public service procurement. At the same time, it highlights the real target of local government procurement, which is to satisfy the diversified need to public service in different regions, and then to realize the target of equalization of public service in whole country, at the last but not least, improving the efficiency of government, saving the fiscal expenditure.

\section{References}

[1] Chen, C., lbekwe-SanJuan, F. and Hou, J. (2010) The Structure and Dynamics of Co-Citation Clusters: A Multiple-Perspective Co-Citation Analysis. Journal of the 
American Society for Information Science and Technology, 61, 1368-1409. https://doi.org/10.1002/asi.21309

[2] Wang, M. and Le, Y. (2008) Analysis of Chinese NGO to Participate in Public Service Purchase Pattern. Journal of Zhejiang Provincial Party School, 4, 5-13.

[3] Han, J.-K. (2009) A Comparison of the Pattern of China's NGO Participating in the Government Purchase Service. Comparative Economic \& Social Systems, 14, 128 134.

[4] Yang, A. (2014) Outsourcing or Insourcing? An Investigation on Insourcing in European and American Countries since 2000. Journal of Public Management, 11, 4958.

[5] Zheng, H. (2014) Dynamic Mechanism and Realization Route of Local Government Purchasing Public Service to Social Organization. Journal of Fujian Party School, 9, 17-22.

[6] Xu, J. and Zhao, T. (2013) The Realistic Dilemma and Path Innovation of Government's Purchase Public Service from Nonprofit Organization: The Case of Shanghai. Chinese Public Administration, 338, 26-30.

[7] Xiang, X. (2015) Study of Boundary Issues in Government Purchasing Public Services in China. Chinese Public Administration, 360, 38-45.

[8] Guangdong Social Work Development Report (2014). http://www.doc88.com/p-3387746298813.html

[9] Department of Civil Affairs of Guangdong Province. http://www.gdmz.gov.cn/gdmz/mzyw/2017-02/21/content_83c53ba5706f428192d19 4913b05f9b1.shtml

[10] The Opinion on the Development and Standardization of Social Organizations in Guangdong Province. http://www.gd.gov.cn/govpub/zfwj/qzb/gdszfwj/200810/t20081030_71713.htm

[11] Regulations of Guangdong Province on Social Organizations (Draft). http://news.163.com/15/0729/14/AVMTSMCA00014JB6.html

[12] Wang, X. (2013) Yunnan: To Build a Solid Institutional Fortress of the Good and Fast Development of Social Organizations. China Social Organization, 29-32.

[13] Cai, N. and Ma, G. (2014) Study on Effect of Social Organizations Participated in Government Purchase Public Service. Times Finance, 544, 48-49.

[14] 2014 Provincial Government Purchasing to Social Organization Service Directory. http://yunnan.mca.gov.cn/article/mzyw/201409/20140900697044.shtml

[15] The Directory of Yunnan Government Purchasing Public Services to Social Organization.

http://www.yn.gov.cn/yn_zwlanmu/qy/wj/yzbf/201509/W020150902593310159979. pdf

[16] Chen, L. and Wang, W. (2013) How to Effectively Promote the Government Purchase Services-Guangdong Provincial Government to Purchase Services Research. China Government Procurement Newspaper, 4, 1-5.

[17] Opinions on Accelerating the Transformation of Government Functions and Deepening the Reform of Administrative Examination and Approval System. http://www.gdbb.gov.cn/detail.jsp?infoid=21495

[18] Yunnan Government Procurement Service Directory. http://yn.yunnan.cn/html/2016-04/10/content_4274287.htm

[19] Wang, Z. (2012) The Demand Change for Public Services from Quantitative to Qualitative. http://china.caixin.com/2012-11-09/100458401.html 
[20] Cai, N. (2014) Study on the Social Organizations Participated in Yunnan Government Purchase Public Service. Master Dissertation, Yunnan University of Finance and Economics, Yunnan.

[21] Lecy, J.D. and Van Slyke, D.M. (2016) Nonprofit Sector Growth and Density: Testing Theories of Government Support. Journal of Public Administration Research and Theory, 23, 189-214. https://doi.org/10.1093/jopart/mus010

Submit or recommend next manuscript to SCIRP and we will provide best service for you:

Accepting pre-submission inquiries through Email, Facebook, LinkedIn, Twitter, etc. A wide selection of journals (inclusive of 9 subjects, more than 200 journals) Providing 24-hour high-quality service User-friendly online submission system Fair and swift peer-review system Efficient typesetting and proofreading procedure Display of the result of downloads and visits, as well as the number of cited articles Maximum dissemination of your research work

Submit your manuscript at: http://papersubmission.scirp.org/ Or contact ajibm@scirp.org 